\title{
THE TURKS OF BULGARIA: AN OUTLIER CASE OF FORCED MIGRATION AND VOLUNTARY RETURN ${ }^{\dagger}$
}

\author{
Muzaffer Kutlay*
}

\begin{abstract}
The Turks of Bulgaria have a particular place in displacement scholarship. As the largest minority population in the country, they were subjected to ethnic cleansing in the 1980s. The anti-Turkish sentiments culminated into state-led systematic exclusion and more than 340,000 Turks were forcefully migrated to Turkey in 1989. After the collapse of Communism and transition to democracy, almost 40 per cent of them voluntarily returned to Bulgaria that makes it an outlier case in displacement literature. Drawing on forty-six semi-structured interviews, this study contributes to the literature by offering a grounded conceptual framework that explains the macro-dynamics of voluntary and sustainable return through an in-depth study of Bulgarian case. The findings suggest that threefactors account for the voluntary return: (i) the peaceful transition to inclusive democracy and power sharing; (ii) the dual moderation between majority and minority representatives; and (iii) the enabling role of international actors, primarily the EUanchor.
\end{abstract}

Key words: Turks of Bulgaria, assimilation, forced migration, displacement, voluntary return.

\footnotetext{
* University of Kent, UK

†An earlier version of this article was presented at the workshop "Peace Processes and Durable Solutions to Displacement" at the British Institute at Ankara on 17-19 April 2015. I would like to express my gratitude to the participants of this workshop, Neophytos Loizides, Djordje Stefanovic and Ayşe Betül Çelik for their invaluable feedback on the initial version of this article as being the organisers of the Workshop and the editors of the Special Issue, along with Işsk Kuşçu for her insightful comments and Birgül Demirtaş for serving as discussant and reflecting very constructive critique. In addition, I extend a warm thanks to Jane O'Mahony and Jenaline Pyle as well as two anonymous referees as this article improved a lot thanks to their exceptionally helpful suggestions and comments. I would like to also thank all interviewees for providing their time for the completion of this research. I retain full responsibility for the views expressed in this article and for any mistakes. Special thanks to Howard Duncan for his excellent editorial support, Sevinc Deliahmed for her kind assistance during my field research and Plamen Ralchev for his generosity as I greatly benefited from his expertise and wide-network. Finally, I am grateful to my doctoral supervisors, Richard G Whitman and Neophytos Loizides who have helped me in developing this research agenda and provided me their invaluable feedback and advice in various stages of this research.
} 


\section{INTRODUCTION}

This study focuses on the macro-dynamics of forced migration of the Turks of Bulgaria and their voluntary return in the aftermath of the country's transition to democracy. Despite being subjected to assimilation policies and forced to leave the country during the final phases of the Communist regime in 1980s, the significant number of voluntary returnees make the Turks of Bulgaria an outlier case in displacement scholarship. ${ }^{1}$ As being the indigenous community and largest minority population in the country, they were often seen as a potential 'destabilising' factor ${ }^{2}$ and Bulgarian Communist Party (hereinafter, BCP) leaders tried hard to overlook their existence either by manipulating or suppressing census data or refuting their ethnic identity. The anti-Turkish sentiments culminated into state-led systematic assimilation and ethnic cleansing policy in the 1980s —notoriously called "national revival process" - and ultimately, over 340,000 Turks were forced to migrate to Turkey in the summer of 1989. After the collapse of the Communist regime and transition to democracy, almost 40 per cent (according to registered numbers 133,272) of them voluntarily returned to Bulgaria (Konukman, 1990: $61,71)$.

The large number of returnees and their peaceful coexistence with the Bulgarian majority make the Turks of Bulgaria a crucial case in the displacement literature. According to Eckstein (1975: 79-138), a case could be considered crucial if it is 'most likely' or 'least likely' concerning the verification of theoretical propositions. The experiences of ethnic cleansing and forced migration, peaceful transformation and voluntary return of the Turks make Bulgaria an example of a 'least likely' case because of its background conditions. In the 1980s, there was vast human suffering marked by an 
systematic assimilation policy including forced name-changing, imprisonments, internal displacements, and finally cross-border forced migration. Yet these repressive measures did not pave the way for a deep-seated protracted conflict between the Bulgarian majority and the Turkish minority. On the contrary, almost 40 per cent of migrated Turks voluntarily returned to their homes — and more importantly — re-integrated into the country's political-economic system. It is also puzzling given the fact that Turkey, the kin state of the Turks in Bulgaria, provided accommodation and financial support to the forced migrants during their initial phase of resettlement in Turkey, ensuring suitable conditions and additional motivation not to return to Bulgaria.

The main finding and argument of this article is that voluntary and sustainable return to Bulgaria became possible due to the simultaneous existence and mutually inclusive interaction of three sets of macro-dynamics at the domestic-international nexus: (i) regime change and the transition to democracy that underpinned the creation of inclusive political institutions in Bulgaria; (ii) 'double moderation' of the majority and minority leaders that represented the Bulgarian and Turkish sides, and (iii) the enabling and complementary role of international actors, particularly the role of EU-anchor. To substantiate the main argument, section 2 sketches out the current literature and states the main research question of the article. Section 3 discusses the methodological approach pursued. Sections 4 and 5 provide a basic overview of the Turks of Bulgaria and discuss the empirical findings with reference to the conceptual framework adopted in this article. The final section extrapolates some lessons for the broader literature. 


\section{LITERATURE AND MAIN QUESTION}

The Bulgarian case is striking from a conceptual viewpoint, as it poses a solid counterexample to the mainstream theories of democratization and ethnic conflict that suggest a different pattern in terms of minority-majority relations. For instance, Mann (2005) argues that democratization is frequently associated with ethnic conflict escalation. $\mathrm{He}$ claims, "ethnic cleansing is the dark side of democracy," as "regimes newly embarked upon democratization are more likely to commit murderous ethnic cleansing than are stable authoritarian regimes" (Mann, 2005: 4). Mann's theory is not supported in the Bulgarian case since democratization correlated with the improvement of inter-ethnic relations between the Turkish minority and the Bulgarian majority. The Bulgarian case also challenges Brubaker's (1996: 4) "theory of triadic relationships." According to Brubaker (1996), the unstable and exploitative nature of the relationship between national minorities, nationalising states, and external national homelands invite conflict potential. This, however, did not turn out to be the case in Bulgarian example. Mansfield and Snyder (2007), similarly, propose that emerging democracies with weak political institutions are more likely to adopt aggressive policies as their leaders attempt to mobilise domestic support by invoking external threats and adopting exclusionary nationalist rhetoric. This was not the case in Bulgaria either, as Turkey showed no interest at all in playing external national homeland through military threat or militant nationalism and the Bulgarian political elite also acted very carefully in order not to invoke nationalist rhetoric. The Bulgarian case, therefore, is a telling example for broader literature to account for the macro-dynamics, which explain the peaceful transition and 
durable return of the displaced people. ${ }^{3}$ Through an in-depth analysis of the Bulgarian case, this article aims to contribute to the relevant body of the literature that explores the underlying conditions. ${ }^{4}$

Several studies in the existing literature extend our knowledge on the state of the Turks in Bulgaria and the ways in which they are acculturated in Bulgarian society. One strand of research deals with the micro-level analysis that is based on extensive ethnographic fieldwork. These studies explore the dynamics of border activities between Bulgaria and Turkey (Parla, 2009), the diverging identity perceptions of Turks who immigrated from Bulgaria and the imminent challenges they encounter (Parla 2006), and the dynamics of irregular migration between Turkey and Bulgaria during 1990s (Parla, 2007). Another striking strand of research, drawing on psychological perspectives, deals with the degree of socio-political integration of Turkish minority in Bulgaria (Dimitrova et. al, 2015). For instance, Radosveta Dimitrova and co-authors provide a very rich comparative account of the acculturation processes of the Turks in Bulgaria (Dimitrova et. al, 2014a) along with other ethnic minorities, primarily Roma people with respect to the ways in which they form their collective identity (Dimitrova, 2013; Dimitrova 2014c). Accordingly, the authors found that "for the Turkish-Bulgarians, adoption and adjustment to the mainstream [Bulgarian] culture are more important possibly due to historical experiences and specific status" (Dimitrova et. al, 2014a: 84), though references to causality in terms of historic experiences are not empirically substantiated. The main reason appears to be the "context", which informed their "acculturation experiences" such as repression, assimilation campaigns, and the severe oppression they encountered (Dimitrova et. al, 2014a: 78). In another important study on Turkish youth in 
Bulgaria, Dimitrova et. al (2014b: 358) indicated that "Turkish-Bulgarian" youth identified with their ethnic origin strongly by holding a complex collective identity that includes "an integration of ethnic Turkish, familial, and religious but not their Bulgarian mainstream identity." In their comparative research on "Turkish-Bulgarians" and "Turkish-Germans", Aydinli-Karakulak and Dimitrova (2015) demonstrated that a contextually differentiated view is required to understand the dynamics of "healthy" identity formation among immigrants. They found that the endorsement of national identity was not adaptive in an assimilative acculturation context, as it was the case in “Turkish-Bulgarians” (also see Dimitrova and Aydinli-Karakulak, 2016). ${ }^{5}$

The current research on the micro-dynamics of integration and acculturation sheds light on the evolution of Turkish minority identity in Bulgaria. The macro-dynamics of peaceful transition and the voluntary return of the Turks, however, are still understudied themes in the literature. Despite the fact that several factors inform the peaceful coexistence and imminent tensions between minority and majority populations in Bulgaria, a vital question remains unanswered in the first instance: How did it become possible to ensure peaceful transition and sustainable voluntary return to Bulgaria, even though the Turkish minority in Bulgaria were subject to systematic oppression and persistent discrimination during the final phases of Communist regime? By addressing the main research question sketched out above, the premise of this article is to contribute to this particular strand of the literature by primarily driving on field research findings and offering a macro-level grounded conceptual framework. 


\section{METHODOLOGY}

This article relies on process tracing to address the main research question. According to George and Bennett (2005: 206), process tracing "identifies the intervening causal

process - the causal chain and causal mechanism — between independent variable[s] and the outcome of the dependent variable." Process tracing enables researchers to assess whether the hypothesized outcome occurs in the sequence and particular causation claimed by the conceptual framework (Hall, 2013). To this end, three types of interview data along with ample primary and secondary sources inform this study. First, forty-six semi-structured interviews were conducted including political elites of Bulgarian and Turkish communities (Lilleker, 2003: 208). Purposive sampling was utilised to unravel and reflect the views of the main actors who were directly involved in the design and implementation of the so called 'national revival process' and leading representatives of the Turkish minority in Bulgaria (Vromen, 2010: 259). ${ }^{6}$ Second, I interviewed families subjected to assimilation and forced migration that subsequently returned to Bulgaria following the collapse of Communist regime to complement elite-level data with the perspectives of ordinary people. ${ }^{7}$ Finally, third-party observers and opinion leaders were also interviewed to gather more information about majority-minority relations and the inner workings of the transformations that took place in Bulgaria. The interviewee sample thus consists of three categories that reflect different perspectives: (i) representatives of main political parties and high-level bureaucrats -including EU officials- in Bulgaria, (ii) representatives of the Turkish minority and the victims of assimilation policy and forced migration, and (iii) informed third party observers who 
closely follow the process in Bulgaria. The overarching rationale for conducting semistructured in-depth elite interviews is to understand how elites on both sides frame the transition period and lead ordinary minority/majority members. Furthermore, ordinary minority members were also interviewed to supplement the elite-level findings. ${ }^{8}$ Each interview comprised of 8 semi-structured open-ended questions. The interviews were conducted in Turkish, English, and Bulgarian. ${ }^{9}$

King, Keohane, and Verba (1994) suggest that the analysis and replication of semi-structured interviews is a challenging task for researchers due to open-ended nature of the interviewees' responses. In this article, following Halperin and Heath (2012: 278), the interview data is analysed in three steps. After reducing the data in field notes and transcriptions, the interview material was "assigned to different categories according to the variable to which they relate" (Halperin and Heath, 2012: 280). Using the research questions and hypotheses as a guide, three broader categories were assigned. First, the data is categorized according to the macro-dynamics that enabled peaceful transformation and voluntary return. Second step was to understand why and how these factors counted. Thus, based on the conceptual framework, the interview data is classified in three subcategories according to the criteria of how interviewees perceived (i) regime change in Bulgaria, (ii) the roles of political leaders on the majority and minority communities during transition period, and (iii) the function of external anchors, particularly the EU, involved in the process. Third, after analysing the data and crosschecking their validity through triangulation, ${ }^{10}$ general conclusions were drawn whether, why, and how peaceful transformation and voluntary return became possible in Bulgarian case. As Silverman (2011) underlines, however, interviews do not provide direct access to the facts and 
realities but enable researchers to have first-hand information about how interviewees have perceived the events. The reliability and validity of the information they provided needs to be crosschecked and substantiated with other sources of data (Dale, 2006: 81). In this context, this article draws on Bulgarian archival documents, newspaper sources, and country reports of the European Council, Helsinki Watch, and European Commission as well as the relevant academic literature.

\section{DISPLACEMENT OF THE TURKS: AN OVERVIEW}

The Turks of Bulgaria are the largest minority group in the country with a population of 588,318 out of 7.4 million according to the 2011 census figures. The demographic composition of the country has changed substantially throughout the history of modern Bulgaria. Prior to the unprecedented exodus of 1989 , there were five other migration waves starting in the early 1900s, which clearly show that the Bulgarian state attempted to keep Turkish minority under political control since the country's independence, especially in the post-1945 period. As Bates documents (1994), Bulgaria's official policies toward the Turks varied significantly during the Cold War. In the initial phase of the Communist regime, the approach toward the Turkish minority was conciliatory and inclusionary (Warhola and Boteva, 2003: 260-264). They were granted special rights especially with respect to education, religious affairs and media freedom. The tolerant approach, however, started to change gradually during the 1960s especially after Todor Zhivkov assumed the leadership of the BCP on 4 March 1954, where he remained in power for 35 years. The Zhivkov and his close aides sought to create a "homogenous Bulgarian state" through various measures (Kalinova, 2014). The repression of ethnic 
minorities became systematic and first targeted Muslim Pomaks during the 1960s (Parla, 2009: 757). In 1971, a new constitution replaced the previous "Dimitrov Constitution" of 1947, which had been in fact tolerant towards minorities as the existence of "national minorities" was explicitly stated. The article 79, in particular, reads as follows:

"The citizens have the right for education. The education is secular, with democratic and progressive spirit. National minorities have the right to learn their mother tongue and to develop their national culture as the learning of Bulgarian language is obligatory."11

The 1971 Constitution, however, was a turning point in majority-minority relations under the auspices of the Zhivkov regime because the term "national minorities" was replaced with "the citizens of non-Bulgarian origin." Following the turbulent 1970s, the exclusionary policies of the regime reached its climax in the winter of 1984-1985 with Zhivkov's announcement of the so-called "national revival process" (vazroditelen protses), which was in fact "an assimilation and ethnic cleansing policy," as retrospectively accepted and condemned by the Bulgarian National Parliament in 2012. ${ }^{12}$

One of the turning points of the assimilation policy was to forcibly slavicize the names of the Turks in the country. The name-changing policy targeted approximately over one million people, most of whom were ethnic Turks. ${ }^{13}$ Based on official documents, eyewitness accounts and victim testimonies, Helsinki Watch Committee reports $(1986,1987)$ documented that hundreds of people were killed and imprisoned on the grounds that they resisted to the involuntary change of their original Turkish names. According to other sources, 517 people were arrested and sent to Belene camp in addition to 400 people who were exiled or imprisoned during the winter of $1984-85$ without any 
prior legal judgement. ${ }^{14}$ In December 1984, several people were killed during the peaceful mass protests against the forced name-changing policy in Killi (Benkovski) and Kayaloba, the villages of Kirkovo in Kardzhali region, where the majority of Turks were living.

In fact, the policy was far beyond a mere name-changing attempt. ${ }^{15}$ As Yalımov stated, "national revival does not only refer to the change in names but also refers to the assimilation of ethnic, religious, and cultural identity of the Turks of Bulgaria by using force." 16 The archival evidence also suggests that the Bulgarization campaign was officially adopted by the BCP Politburo, and implemented as part of a comprehensive set of measures. ${ }^{17}$ Accordingly, all kinds of public communication in Turkish language were denied. Those in violation of the ban were levied heavy fines. Associations, newspapers and cultural and musical activities related to 'Turks' and 'Turkishness' were also banned. Similarly, Islamic holidays were cancelled and religious freedom was set aside to the extent that Turks were not allowed to wear their traditional trouser "şalvar" in public. ${ }^{18}$ The assimilation policy was also designed as an intimidation to other minority groups, as the Turks were compelled to write their new Slavic-Bulgarian names on the gates of their houses. The homogenization policies were as widespread and methodical to the extent that the civil servants even erased the Turkish names on the tombstones (Ataöv, 1990: 2). The name-changing policy was carried out systematically with an ultimate aim to deny the existence of the Turks of Bulgaria. ${ }^{19}$

The Turkish minority launched waves of peaceful protests that included hunger strikes, daily letters to state institutions, and mass demonstrations in early 1989 to resist the assimilation policy and to restore their rights. In May 1989, the protests intensified 
and people gathered in the city centres so as to attract the attention of the international community. Their goal was to call on the Bulgarian government to protect fundamental rights and freedoms of Turks as well as to put an end to the constantly expanding sanctions and internal displacements (Dayığlu, 2005: 345-347). It soon became apparent that the protests were falling on deaf ears, as the counter-policy of Zhivkov was very harsh. On 29 May 1989, Zhivkov announced on Bulgarian National Television and Bulgarian National Radio that borders "were now open and anyone could leave Bulgaria." ${ }^{20}$ The Ministry of Internal Affairs prepared and distributed special application forms for international passports among Turkish people that settled the administrative infrastructure of forced migration (Bakalova, 2006: 235). The mass deportation of Turks, which began in mid-1989, resulted in the migration of more than 340,000 people to Turkey by the end of August, for many, after leaving all their properties and belongings on the Bulgarian side of the border. ${ }^{21}$

\section{THE DYNAMICS OF VOLUNTARY RETURN OF THE TURKS}

The domestic and international dynamics during the 1990s dramatically changed the nature of majority-minority relations in Bulgaria. First and foremost, over one-third of displaced Turks returned to Bulgaria on a voluntary basis. The voluntary return endured sustainably because, even after tortuous legal processes, these people restored their rights and became integral parts of Bulgaria's economic, political and social life. Based on field research findings in Bulgaria, in this part, I shall propose a grounded framework that three sets of interrelated macro-dynamics stand out as the main causes of feasible and sustainable return. 


\section{Peaceful transition to democracy and institutional design}

The first set of factors is related to Bulgaria's peaceful transition to democracy in the immediate aftermath of the collapse of Communist regime. Todov Zhivkov was dethroned on 10 November 1989 with a "palace coup," designed and undertaken within the higher echelons of the BCP (Baeva, 2004: 297-325; Crampton, 1997: 216). The dethronement of Zhivkov marked a tipping-point not only in Bulgarian politics but also for the trajectory of Turkish minority in the country.

Zhivkov was ousted due to three main reasons. First, the crises of the Communist regimes in Central and Eastern Europe at the time unsurprisingly hit the shores of the Bulgarian political system as well. Accordingly, the $\mathrm{BCP}$ rulers found themselves in a delicate position concerning the transformation of the political system. As demands for political liberalization intensified, different opposition factions emerged around the country and inside the BCP. The rising domestic opposition as well as the changing international atmosphere triggered by popular revolts against totalitarian regimes including Bulgaria's neighbour, Romania, forced the BCP elite to implement certain reforms. The first step in this direction was the removal of Todor Zhivkov. Civil society opposition intensified as fourteen non-communist groups formed a political platform in November 1989 to promote political pluralism in Bulgaria. The non-communist groups formed the Union of Democratic Forces (hereinafter, UDF) and elected Zhelyu Zhelev as their leader who subsequently became the first democratically elected President of Bulgaria. ${ }^{22}$ The UDF became a very influential platform that promoted democratization and non-violent transformation in the country. 
Second, the worsening economic conditions in Bulgaria accelerated the end of Zhivkov regime. The Bulgarian economy was plunged into structural difficulties starting from the second half of the 1980s. Volatility in growth and export figures, especially rising inflation after 1988, and worsening living conditions aroused the anger of masses against the BCP (Crampton, 1997: 217). On top of that, the economy encountered a severe production crisis due to the forced migration of the Turks as they were mainly employed in agricultural sector and their exodus contributed to poor harvests, which in turn, led to the extension of food rationing from rural areas to the provinces of Sofia. ${ }^{23}$ After the removal of Zhivkov, it became apparent that economic performance indicators were in fact worse than the regime's fabricated numbers. The foreign debt of the country, for instance, stood not "at 3 billion dollars admitted by Zhivkov, but at 12 billion dollars" (Crampton, 1997: 217).

Third, the so-called 'national revival' policies of Zhivkov regime and the mass exodus of the Turkish minority sparked a debate within the country and across international platforms, which in turn, created a boomerang effect against Zhivkov. Beginning in mid-December 1989, the Turkish minority organized a series of protests for the restoration of their original Turkish names. In this regard, the "silent presence" protest in front of the Parliament on 28 December 1989 constituted a watershed moment (Dayığlu, 2005: 376). The official policy change of the BCP was publicised with Alexander Lilov's report, a member of the first echelon party faction, which openly denounced the policies of Zhivkov. The report, entitled To Overcome the Distortions among the Turkish-Speaking and Muslim Population in Bulgaria, accepted the Turks' rights to exercise all of their religious and ethnic rights provided by the original 
Constitution (Dimitrov, 2000). Bakalova (2006: 236) argues that this paradigmatic change might also be interpreted as a "perfect hand-washing manoeuvre" because by doing so the ruling Communist Party elites promoted the idea that "national revival process" was not in fact a party policy and the whole party could not be held responsible for the mistakes of the Zhivkov era. ${ }^{24}$ Lilov, in his report, also underlined the increasing international criticisms in the sense that it was by no means possible for the ruling elite to justify the assimilation policy and convince the international community about the mass exodus of the Turkish minority. In this context, policy change turned into a necessity, rather than a choice, to avoid the isolation of Bulgaria in its international relations (Poulton, 1993: 163). Accordingly, a name-restoration policy was officially declared, which readmitted the rights of the Turks to freely choose their names, conduct their religious affairs, and learn their native language (Dayığlu, 2006: 376).

The Bulgarian state's reconciliation policies were evident in a series of public apologies and acknowledgements of crimes committed during the "national revival process." In the early transition period, it was not possible for Bulgarian ruling elites to officially apologise due to the strong domestic opposition and audience costs. Despite the fact that Communism was denounced by the masses, the nationalist sentiments that strongly opposed to restoration of the Turks' minority rights were still sufficiently evident to force Bulgarian officials to act in a cautious manner. ${ }^{25}$ On that note, it was only after the second half of the 1990s that the Bulgarian officials apologised to the Turkish minority on different occasions. Inter alia, then Bulgarian President Peter Stoyanov apologised to the Turks in his speech at Turkish Parliament in Ankara in 1997 and more recently, in 2012, the Bulgarian Parliament signed a historical declaration that defined the 
assimilation process as "ethnic cleansing" and officially condemned the 1989 forced migration (Kutlay, 2012). Interview data suggest that in addition to the quick restoration of the rights of Turkish minority, the subsequent public apologies and the official acknowledgement of crimes committed against the Turkish minority boosted the sense of security for the returnees. The interviewees, especially, hailed the latter point as 75 per cent of them responded that the state apology and acknowledgement of crimes had a very positive impact on majority-minority relations in Bulgaria.

\section{The importance of double moderation}

The second set of factors that informed peaceful transition in Bulgaria and the voluntary return of the Turks in the aftermath of Zhivkov's regime is the 'double moderation' of majority and minority leaders. The literature suggests that the policies and actions of political leaders are among major causes of conflicts (Korostelina, 2009). Accordingly, leaders play a vital role in mobilizing social movements, dividing groups, and increasing mistrust among them. Political leaders can be crucial catalysts to start and stop the use of organized political violence. The interview data suggest that, from a political entrepreneurship point of view, conciliatory leadership on the side of Bulgarian policymakers and Turkish minority feed into each other and enfeebled conflict risk during the most sensitive critical junctures. ${ }^{26}$

Accordingly, two leaders, both Zhelyu Zhelev and Ahmet Doğan, played significantly facilitating roles to mitigate the conflict potential. First, Bulgaria's democratically elected President Zhelyu Zhelev was an anti-communist with strong 
liberal tendencies. In fact, in the aftermath of Bulgaria's transition to democracy, he treated the Turkish minority as an ally in consolidating democratic practices and ensuring Bulgaria's integration into the Euro-Atlantic structures. ${ }^{27}$ To this end, Zhelev actively supported the initiatives to secure the participation of the Turkish MPs in the Bulgarian Parliament, despite popular nationalist protests against the Turkish representatives in 1990. Thanks to the political moderation and conciliatory politics advocated by Zhelev and his close aides, soon after the regime change, the Turkish minority established their own political party in March 1990 under the leadership of Ahmet Doğan, which was named Movement for Rights and Freedoms (hereinafter, MRF - Hak ve Özgürlükler Hareketi in Turkish. The MRF became an active player in Bulgarian politics and was represented in the Bulgarian Parliament in all elections during the transition period (Eminov, 1999: 40; see table 1 below).

\begin{tabular}{|c|c|c|c|c|c|c|}
\hline & \multicolumn{2}{|c|}{1990} & \multicolumn{2}{|c|}{1991} & \multicolumn{2}{|c|}{1994} \\
\hline & Number & Percentage & Number & Percentage & Number & Percentage \\
\hline BSP & 211 & 47.2 & 110 & 45.8 & 125 & 52.1 \\
\hline UDF & 144 & 36.2 & 106 & 44.2 & 69 & 28.8 \\
\hline MRF & 23 & 6.0 & 24 & 10.0 & 15 & 6.2 \\
\hline BANU & 16 & 8.0 & -- & -- & -- & -- \\
\hline PU & -- & -- & -- & -- & 18 & 7.5 \\
\hline BBB & -- & -- & -- & -- & 13 & 5.4 \\
\hline Others & 6 & -- & -- & -- & -- & -- \\
\hline Total & 400 & 100.0 & 240 & 100.0 & 240 & 100.0 \\
\hline
\end{tabular}

The establishment of MRF as a political party was by no means an easy task. The fourth paragraph of article 11(1) of the Bulgarian Constitution adopted on 12 July 1991 states that "there shall be no political parties on ethnic, racial, and religious lines..."28 The Political Party Act also incorporated the same principle before the adoption of the 
new Constitution. Bulgarian nationalists tried to ban MRF twice on the grounds that MRF was in breach of the Political Party Act and article 11(1) of the Constitution. The first attempt came just before the 1990 elections, in which MRF also aimed to take part. Accordingly, Sofia City Court and the Supreme Court denied MRF's attempt to register as a political party prior to the 1990 elections. The Central Electoral Commission, however, granted permission to the party to register and attend the June 1990 elections (Nitzova, 1997: 729-739). The second attempt to ban the MRF, which was headed by Bulgarian Socialist Party members, materialized in late 1991 (Eminov, 1999). The Bulgarian deputies filed a petition at the Constitutional Court on the ground that MRF was violating article $44(2)$ of Bulgarian Constitution, which prohibits acting to "the detriment of the country's sovereignty and national integrity." Thanks to the brinkmanship of Zhelyu Zhelev, the Constitutional Court rejected the application of nationalist deputies and decided that MRF could continue its existence as a political party (Kolarova, 1993: 23-51). According to Plamen Bogoev, legal counsel at Sofia City Court and the legal advisor to President Zhelev, "the judgement of the Constitutional Court on Constitutional Case \#1/1991 was a definite contribution both to the democratic process in the country and to the supremacy of law" (Bogoev, 2000: 190). The MRF's forbearance and representation in the Bulgarian Parliament provided vital political opportunities for the Turkish minority to restore their religious and linguistic rights in addition to the political reclamations.

The 1991 Constitution, approved by the Parliament in which MRF also took active part, was an important yardstick in this regard. Article 13 of the Constitution asserted that "(1) the practising of any religion shall be free (2) the religious institutions 
shall be separate from the state..." Article 37, moreover, acknowledges the "state shall assist the maintenance of tolerance and respect among believers from different denominations..." Accordingly, during 1990s, the religious schools were reopened. In addition, the mass publication of the Qur'an in Bulgarian and Turkish languages was legalized along with the right for Muslims to pray in mosques (Lewis, 1994: 20-29). The Turkish minority also improved their ethno-linguistic rights. The complex legal procedure was amended in 1991 thanks to the policies pursued by the MRF at the Bulgarian Parliament. After the legal amendments, the overwhelming majority of the people belonging to the Turkish minority filed petitions to the relevant state authorities to revert back to their Turkish names, as a result of which the number of applications reached 600,000 in March 1991 (Dayığlu, 2006: 381). The 1991 Constitution envisioned certain rights for non-ethnic Bulgarian citizens to study in their native language as well. Accordingly, these minority groups were enabled to establish private schools (article 53) and recognized the right of every citizen "to avail himself of the national and universal cultural values and to develop his own culture in accordance with his ethnic selfidentification" (article 54). The constitutional changes were significant in terms of the socio-political conditions of Turkish minority in Bulgaria because they constituted a clear policy change toward the Turks in comparison to the repressive policies pursued by Zhivkov regime. In the words of Eminov, "after a hiatus of more than 20 years, Turkish children once again would be provided instruction in their mother tongue" (Eminov, 1999: 48). ${ }^{29}$

In the early years of transition, thanks to Zhelyu Zhelev, the Bulgarian state pursued conciliatory policies regarding the minority issues. The integrationist strategy of 
the new Bulgarian elite proved effective in preventing die-hard nationalists from dominating the conflict. Similarly, the Turkish minority leader Ahmed Doğan also demonstrated much-needed political entrepreneurship in averting possible violent conflict. Even during his time in prison in the 1980s, Doğan sent orders to his followers not to resort to violent tactics (Eminov, 1999: 40). Ahmet Doğan also acted in a decisive manner to put the MRF into a moderate track by marginalizing ultra-nationalist rhetoric within the party echelons. ${ }^{30}$ After the fall of the Zhivkov regime, through the MRF, Doğan secured the participation of Turkish minority into the governance of the country. There was a delicate balance at that time and the role of MRF was quite important in terms of alleviating the inter-communal tension. In fact, the MRF never called for independence or autonomy for the Turks. ${ }^{31}$ The party leaders did not even push for the recognition of the Turks as "national minority.” As Krassimir Kanev underlined, "Turks' demands were minimalist. They just asked for their basic rights and freedoms. They never asked for autonomy and/or independence." 32 The major policy of the MRF was to improve the rights of the Turks and their participation into the political, social, and economic life in the country as equal citizens along with ethnic Bulgarians. ${ }^{33}$ Tsvetan Tsvetanov, Bulgarian Minister of the Interior, acknowledged the role of MRF as follows:

MRF has really helped to avoid any ethnic conflicts in the country. They have also participated; alongside with the all other political parties in the Bulgarian Parliament, in the preparations to join NATO and the EU and they have supported [the democratization] process like all other political parties. ${ }^{34}$

A retrospective analysis reveals that both Zhelev and Doğan found a common adversary, i.e. the ancien régime, to struggle against to materialize their particular 
policies. As Mihail Ivanov, President Zhelev's adviser at the time, stated "[during the transition period], the newly formed democratic opposition determined Communist regime as common enemy [in order to prevent an ethnic clash between Bulgarians and Turks]. ${ }^{35}$ The Turkish elites also resorted to the same idea. For instance, as Yalımov claims, "during transition period, Communism [as the ideology] was declared as the main culprit. This approach calmed people on both sides and avoided the emergence of an ethnic conflict." ${ }^{36}$ The common adversary for both parties, once combined with the political entrepreneurship of both sides, brought double moderation that facilitated peaceful transformation and smooth integration of the Turkish minority into Bulgarian socio-political life that informed sustainable return of the displaced Turks.

\section{The complementary role of international actors}

The third set of factors relate to the enabling and complementary role of the international actors that further facilitated the voluntary return through invoking the cultural and minority rights of the Turks of Bulgaria. The most important facilitator, in this context, is found to be the EU anchor. The data suggest that the allure of the future EU membership played a significant, though complementary, role in moderating the nationalist backlash against minorities. In the broader Balkan and Eastern European region, the EU is one of the best examples often cited to underline the positive effects of globalization and regional integration based on democracy and the market economy (Vachudova, 2005). Bulgaria's transition to democracy in the 1990s and its eventual entry into the EU in 2007 positively informed the peaceful resolution of the identity-based conflicts as the conditions imposed by Brussels on Sofia for full membership helped to curb nationalist and discriminatory tendencies in Bulgarian politics. ${ }^{37}$ Therefore, it appears that the 
scrutiny by the EU institutions was serious, real, and continuous. A recent article of New York Times, for instance, also appraises Bulgaria as a country with stable inclusive institutions thanks to the EU oversight and guidance (Dzhambazova, 2017).

The EU's role, however, evolved over time. In the first phase of Bulgaria's transition to democracy, the EU played a rather complementary role in terms of restoring the rights of Turkish minority in Bulgaria. The macro-goal of returning to Europe provided a benchmark for the political elites of both majority and minority representatives. In the words of Baeva and Kalinova, “the EU's role can be detected in the pressure for [minority rights]. It was especially true during the 1990s, when the EU's position was that the MRF's presence in the Parliament was a necessary condition for Bulgaria to proceed with the negotiations." ${ }^{38}$ Furthermore, the displacement literature suggests that security provisions emerge as a crucial explanatory factor that boosts the success of voluntary return rates. ${ }^{39}$ Accordingly, Bulgaria's determined attempts to reform its governance structures along with the European rules and norms facilitated the re-integration of Turks into Bulgarian society since the EU was also conceived as a kind of guarantor and security provider. As Hakov succinctly points out, "the 1989 events will never be repeated again as long as Bulgaria remains part of the EU." ${ }^{40}$ Ahmed Doğan, for instance, firmly believed that the rights of the Turkish minority would best be secured within the Euro-Atlantic structures. ${ }^{41}$

The impact of the EU became more direct and unequivocal after Bulgaria's official candidacy in 1999, which can be described as a period of intense Europeanization in Bulgarian politics. In this period, the EU's transformative power over Bulgaria increased significantly due to the EU conditionality attached to membership prospects 
(Papadimitriou and Gateva, 2009: 161; Phinnemore, 2009: 241). Since Bulgaria's goal was to become an EU member state, Bulgarian policy-makers intensified their attempts to adopt the EU acquis. In terms of minority rights and the state of Turkish minority, significant improvements took place during this period. First, the Bulgarian Parliament ratified the Framework Convention in May 1999. The ratification process was painful because the nationalist groups appealed to Constitutional Court to contest the term 'national minorities.' The Constitutional Court, having taken Bulgaria's candidacy status into consideration, rejected the application and the Framework Convention was implemented. ${ }^{42}$ Second, the Race Equality Directive (Council Directive 2000/43) was adopted as part of EU acquis in 2000 to "lay down a framework for combating discrimination on the grounds of racial or ethnic origin, with a view to putting into effect in the Member States the principle of equal treatment" (article 1). ${ }^{43}$ The Directive prohibits direct and indirect discrimination in employment, the labour market, social protection, education, and access to public goods. The European Commission, in its regular progress reports, requested Bulgaria to comply with the Race Equality Directive (EC, 2004: 25-26). The Directive was quite important for the Turkish minority because they suffered from the implicit discrimination in their attempts to participate in economic and political life in Bulgaria. ${ }^{44}$

As several researchers highlight, one should not underestimate at this point that substantial challenges persist concerning Bulgaria's overall democratization performance (Noutcheva and Bechev, 2008). The performance of Bulgarian governments during the protracted Europeanization process and the Bulgarian public's attitudes towards Turkish minority suggest that internalization of European norms still remains a work in progress. 
On that note, public surveys do not imply a cognitive shift as the evidence suggests that an overwhelming majority of Bulgarians still perceive Turkish minority as a 'threat' rather than appreciating multiculturalism. The public surveys conducted by Krassimir Kanev and his team are illuminating in this regard (Kanev, 2007: 79-88). Accordingly, 69 per cent of Bulgarian citizens perceive Turks as "religious fanatics" and 69 per cent agree with the statement "Turks have occupied too many positions in the government." The daily social interactions between Turkish minority and ethnic Bulgarians also encounter difficulties. The available data hint that the inter-communal relations between the Turks and ethnic Bulgarians are overshadowed by historical prejudices and doubts. The rights that Turks gained during the democratization process seem to disturb the Bulgarian majority as it becomes apparent by the rise of xenophobic ATAKA party. On the other hand, the data suggests that despite the fact that Turkish minority appears to be satisfied with the official apology of the Bulgarian state, trust problems still prevail beneath the surface as none of the perpetrators have been brought to the courts and sentenced for their crimes during the "national revival process." ${ }^{45}$ Despite all these obstacles, in the final analysis, it is nevertheless possible to maintain that the Europeanization of the Bulgarian minority rights regime informed better integration of the Turkish minority into Bulgarian society, which created conducive macro-environment for the returnee Turks to sustain their order in the country (Rechel, 2007; 2008: 175). It appears, however, that the EU factor emerged as a complementary rather than a constitutive element in the transition years that further motivated the voluntary and sustainable return of the forcibly migrated Turks. 


\section{LIMITATIONS OF THE PRESENT STUDY}

The research findings, while shedding light on an under researched case in displacement literature, also have certain limitations. First, the interview data analysed in this article should be complemented and checked with other research techniques to replicate and triangulate the findings. The research inferences should be checked with new interviewers and through different interviewee samples as the data in this study gathered by one interviewer. Though it is a common practice in political science to conduct qualitative research with one interviewer, it would be useful to check the findings with more interviewers to increase the reliability of inferences. In addition, large-n survey data compiled from the Turks of Bulgaria would shed fresh light, especially on the micro-dynamics of voluntary return. Large-n surveys would not only enable gathering systematic data at the non-elite level due to the larger sample size but also provide opportunities to mitigate the potential impacts of varying degrees of cultural/linguistic mismatch between the interviewer and interviewees. Second, the grounded macro-level framework proposed in this article should also be tested in other forced migration cases to reveal the causal mechanisms and inner workings in a comparative perspective. In conclusion, however, it is the premise of this research that, by studying Bulgaria as a crucial case, the present research makes conceptual and empirical contributions to the relevant body of literature on inter-ethnic conflicts and voluntary return of forcibly displaced people. 


\section{CONCLUSION}

Almost 40 per cent of Turks that were subjected to forced migration in late 1980s, voluntarily returned to Bulgaria, despite earlier harsh assimilation policies and massive human suffering. This is quite a striking case that deserves close analysis as it poses a counter-example to the mainstream democratization theories in the literature predicting conflict. The studies of Mann, Brubaker, and Mansfield and Snyder, for instance, predict the escalation of inter-ethnic conflict as one likely, but presumably unintended, outcomes of democratization. The Bulgarian case, however, tells a different story, which makes it an outlier in the literature. Drawing on forty-six semi-structured interviews, this article offered a grounded conceptual framework extrapolating three main context-specific macro-level factors that facilitated peaceful voluntary return of the forcibly displaced Turkish minority in Bulgaria.

First, the assimilation campaign towards the Turks did not lead to a violent conflict between parties. While neighbouring Yugoslavia was torn apart by deadly violence, Bulgaria remained relatively peaceful "despite similar religious divides, severe economic hardships, and massive social and political changes that followed the arrival of democracy and free markets" (Ghodsee, 2009: 12). Even substantial problems related to Bulgaria's democratization performance still persist; the peaceful transition to democracy opened a window of opportunity for the Turks to be represented in the governing institutions of the country. The establishment of the MRF as the political party of Turkish minority provided a legitimate platform to raise their demands and concerns. Second, double moderation of the majority and minority groups in Bulgaria facilitated voluntary return in the post-Communist era. In this sense, one should give credit to Zhelyu Zhelev 
and Ahmet Doğan as political entrepreneurs and the architects of 'double moderation' since both leaders acted in a way that enfeebled conflict potential and underpinned intercommunal reconciliation. Finally, external factors, particularly the EU, played a rather complementary function by expanding and guaranteeing minority rights in Bulgaria and encouraging their inclusion to the Bulgarian social-political system, and evoking the economic, political and cultural rights to the minority groups.

\section{NOTES}

\footnotetext{
${ }^{1}$ For a discussion on voluntary and forced migration, see: Yarris and Castaneda (2015).

${ }^{2}$ Todor Jivkov explicitly mentions in his speech while addressing BCP Politburo members and BCP Central Committee members on 18 January 1985 by saying that "We are in this situation since 9 September. Turks are located in the very important border regions. Think Kardzhali for example, this region is mostly populated by Turks. Kardzhali region is the heart of South and key to the entire Rodopi region. We recently realised that if there is a potential war, Turks are already holding the strategic points. Today, we should take the advantage of Turkey's current conflict with Greece and implement our action plan offered by Georgi Atasanov". Georgi Atasanov (1933) is the then Prime Minister of Bulgarian People's Republic. At the end of his speech, Jivkov refers to Kardzhali region as being the fortress of Turkish people. For the original Bulgarian version, see, Dirjavna Agentsiya "Arhivi” (2009: 217-219); for Turkish version, see, Mevsim (2013: 9-10).

${ }^{3}$ There is a voluminous literature on different aspects of forced migration and displacement. For a comprehensive survey on the literature, see Elena Fiddian-Qasmiyeh at. al. (2014). Among others, national development objectives, which were also the case in the Soviet Bulgaria, is also one of the motivations of internal displacement and forced migration practices. For a discussion on development-created population displacement, especially in the Soviet sphere, see McDowell (2014).

${ }^{4}$ For a literature review and theory-informed discussion on the issue, see, Stefanovic and Loizides (2011). For an exception of the Bulgarian case, see, Parla (2006).

${ }^{5}$ As the authors extensively discuss through "multiple social identities" concept, the usage of "TurkishBulgarians" or "Bulgarian Turks" are still not acceptable among the Turks of Bulgaria as it implies a misperception that leads to a wrong implication of them belonging to Bulgarian ethnicity, as this is exactly what was imposed in the 1980s showing itself, for instance, enforcing Bulgarian names.

${ }^{6}$ I followed the same sampling procedures for all samples that are selected through of purposive sampling method.

${ }^{7}$ In this category I interviewed with eight families living in northern (Isperih, Shumen, Razgrad) and southern (Delchevo, Krumovgrad, Ardino) provinces of Bulgaria and in Sofia, the capital city. The interview sample with the families represents geographical diversity of the Turkish minority living in Bulgaria. In each region, the interviewees are selected through snowballing sampling technique.

${ }^{8}$ See note 7.

${ }^{9} \mathrm{I}$ am fluent in Turkish and English. The two of the interviews are conducted in Bulgarian with the help of an interpretive native in Turkish and Bulgarian. There was no indication that my presence as an out-group member had an influence on the interviews. Since the research question deals with an historical issue, the
} 
risk of social desirability bias is considered low. Nevertheless, the commonly used procedures are applied to mitigate social desirability bias. Accordingly, the interview questions were articulated in a neutral manner, indirect questioning was used, and utmost attention was paid to avoid favouring any particular viewpoint (for details, see Byrne, 2004: 182; Aberbach and Rockman, 2002).

${ }^{10}$ I applied triangulation technique to check and verify the data provided by the respondents. The data gathered through interviews are compared with archival materials on the subject matter, the secondary literature, and with the answers of other respondents where applicable. For the use of triangulation technique and its importance for qualitative research in political science, see George and Bennett (2005).

${ }^{11}$ The Constitution of the People's Republic of Bulgaria, 1947. Available online at: http://www.parliament.bg/bg/18 (accessed on 12 May 2016).

${ }_{12}$ The official text of the Parliamentary declaration is available online at: http://www.parliament.bg/bg/declaration/ID/13813 (accessed on 7 June 2016)

${ }^{13}$ Bakalova mentions that the number was around 850,000 people (see, Bakalova, 2006: 234). However, according to an official letter prepared by Bulgarian Ministry of Interior to be sent to Ministry of Defence and National Security, the names of 1,306,000 people were changed in 1984-1985. The letter is prepared by T. Bobev and signed by First Deputy Minister General Grigor Şopov on 27 May 1989. See, Republic of Bulgaria, Ministry of Interior, 1989.

${ }^{14}$ Due to the lack of official records, the exact number of Belene victims and internally displaced people are still unclear. These numbers are based on author's interview with Mehmet Niyazi, The Secretary General of BAHAD - the Association of Justice, Rights, Culture and Solidarity of Belene Camp Victims, March 28, 2015.

${ }^{15}$ After painful years in Belene Camp, these people were conditionally released in the spring of 1987 and internally displaced to the districts entirely populated by Bulgarians. For an extensive and biographical documentation regarding the memories of victims, see, Mevsim and Kutlay (2013).

${ }^{16}$ Author's interview with İbrahim Yalımov, Professor, then Rector of Sofia High Institute of Islam, April 27, 2010.

${ }^{17}$ State Archive Agency Bulgaria published the Bulgarian Communist Party Politburo Archives on "National Revival Process" in two volumes, see, Dirjavna Agentsiya "Arhivi" (2009).

${ }^{18}$ Author's interview with İ. Yalımov (2010).

${ }^{19}$ Todor Jivkov's speech on the consequences of name-changing policy in a meeting with the participation of BCP Politburo members, BCP Central Commitee members and BCP local government representatives on 18 January 1985. For the original Bulgarian version, see, Dirjavna Agentsiya “Arhivi” (2009: 217-219); for Turkish version, see, Mevsim (2013: 9-10).

${ }^{20}$ For the full text of Zhivkov's speech, in Turkish, see, Mevsim (2013: 20-27). For the original Bulgarian version, see Dirjavna Agentsiya “Arhivi” (2009: 517-519).

${ }^{21}$ Author's field notes during her visits to the families who were subjected to forced migration of 1989, October 22-25, 2011, Bursa/Turkey; January 12-22, 2012, Kardzhali/Bulgaria.

${ }^{22}$ For an autobiographic history of the transformation period in Bulgaria, see, Zhelev (2008).

${ }^{23}$ Author's interview with Cengiz Hakov, Professor, Bulgarian Academy of Science, Institute for Balkan Studies, May 4, 2010.

${ }^{24}$ Author's interview with a Bulgarian political analyst, May 26, 2010. Author's interview with Mihail Ivanov, adviser on minority issues to then Bulgarian President Zhelyu Zhelev, May 7, 2010. Author's interview with İ. Yalımov (2010). Author's interview with Dr. Yordanka Bibina, a Bulgarian academic, Bulgarian Academy of Science, Institute for Balkans Studies, May 9, 2010.

${ }^{25}$ Author's interview with M. Ivanov (2010).

${ }^{26}$ Author's interview with M. Ivanov (2010). Author's interview with Ruşen Rıza, Deputy Head of MRF May 26, 2010. Author's interview with Hasan Azis, Mayor of Kardzhali Municipality on May 8, 2015.

${ }^{27}$ Author's interview with Zhelyu Zhelev, first democratically-elected President of Bulgaria, May 21, 2010.

${ }^{28}$ The Constitution of Bulgaria, 1991. Available online at: http://www.parliament.bg/en/const (accessed on 20 June 2016).

${ }^{29}$ The changes on article, however, did not mean automatic spill over in practice. The nationalist segments of Bulgarian political parties pushed hard to postpone the implementation of these rights especially during BSP governments. For example, in December 1994, after the rise of BSP as the governing party, Ilcho Dimitrov was appointed as the Minister of Education. Dimitrov was one of the staunch supporters of Zhivkov government's assimilation policies and he appointed officials as inspectors with anti-Turkish 
sentiments to the areas where Turkish minority was composing the overwhelming majority of the population. These officials' main duties were to change the curricula of Turkish classes and disrupt the appropriate implementations of the linguistic rights at the schools. After being appointed as MoE, Dimitrov played a key role in making Turkish classes optional before and after the normal school hours even in the villages where Turkish minority was overwhelming. Since Turkish classes were not compulsory anymore, it significantly decreased the number of children attending the classes. The broadcasting in Turkish language was another contentious issue. Although the 1991 constitution enabled the Turkish minority to broadcast in their native language, the actual means of conducting this right was not provided till 2000s. Currently, it is only 10-15 minutes long afternoon news broadcasting which is considered inadequate by Turkish Minority. Author's interview with İzzet İsmailov, Editor in Chief, Turkish News Broadcasting Service, Bulgarian National Television, May 19, 2010).

${ }^{30}$ Author's interview with Ahmet Hüseyin, former MP of MRF, May 10, 2010. He stated, "Ahmet Doğan clearly rejected the maximalist demands and cut the ultra-nationalist members' links with the MRF." Also, the first party programme of MRF, which was declared and accepted in the March Founding Conference, lists the Party's priority principles as "pursuing peaceful and constitutional ways to claim their rights" and "rejecting any kind of terrorism and violent activities as a means of accomplishing political aims" (See, Özgür, 1999: 97)

${ }^{31}$ Author's interview with R. Riza (2010).

${ }^{32}$ Author's interview with Krassimir Kanev, Chairman of Bulgarian Helsinki Committee, May 4, 2010.

${ }^{33}$ Author's interview with R. Riza (2010).

${ }^{34}$ Author's interview with Tsvetan Tsvetanov, Bulgarian Minister of Interior (2009-2013), May 28, 2010.

${ }^{35}$ Author's interview with M. Ivanov (2010).

${ }^{36}$ Author's interview with İ. Yalımov (2010).

${ }^{37}$ For the positive role of the EU in transforming conflicts through conditionality, see, Diez et al. (2008); Rumelili (2007).

${ }^{38}$ Author's interview with Professor Iskra Baeva and Professor Evgenia Kalinova, Sofia University St. Kliment Ohdriski, October 17, 2012.

${ }^{39}$ For an elaborative account, see, Stefanovic, Loizides and Parsons (2014).

${ }^{40}$ Author's interview with Cengiz Hakov, October 9, 2012.

${ }^{41}$ Author's interview with R. Riza (2010).

${ }^{42}$ For the full-text, see, "Framework Convention for the Protection of National Minorities". Available online at: http://conventions.coe.int/Treaty/en/Treaties/html/157.htm (accessed on 30 September 2016).

${ }^{43}$ Council Directive 2000/43/EC of 29 June 2000 implementing the principle of equal treatment between persons irrespective of racial or ethnic origin, Official Journal L 180, 19/07/2000 P. 0022-0026. Available online at http://eur-lex.europa.eu/LexUriServ/LexUriServ.do?uri=CELEX:32000L0043:EN:HTML (accessed on 5 January 5 2015).

${ }^{44}$ Author's interview with a high level official who works for the Commission for Protection against Discrimination in Bulgaria. For the reasons of confidentiality, the name is not mentioned.

${ }^{45}$ Half of the interviewees put strong emphasis on this point.

\section{REFERENCES}

Aberbach, J.D. and B.A. Rockman

2002 "Conducting and Coding Elite Interviews", PS: Political Science and Politics, 35(4): 673-676.

Aydinli-Karakulak A. and Dimitrova R.

2015 "Brief report: When does identity lead to negative affective experiences? A comparison of Turkish-Bulgarian and Turkish-German adolescents", Journal of Adolescence, 47: 125-130.

Ataöv, T.

1990 The Inquisiton of the Late 1980s: The Turks of Bulgaria, Washington: EAFORD; 135-152. 
Baeva, I.

2004 "Political Changes in Bulgaria during the Years of Globalization" in Vasil Prodanov (Ed),

Bulgaria in Global Processes, Global Scholarly Publications, New York: 297-325.

Bakalova, M.

2006 “The Bulgarian Turkish Names Conflict and Democratic Transition”, Innovation, 19 (3/4): 233-

246.

Bates, D.G.

1994 "What's in a name? Minorities, identity, and politics in Bulgaria", Identities: Global Studies in Culture and Power, 1(2/3): 201-225.

Bogoev, P.

2000 "The Bulgarian Constitution and Minority Rights", in 1989-1999, Ten Years Later: Lessons

Learned for the Future, Scorpion Publishing House, Sofia.

Brubaker, R.

1996 Nationalism Reframed: Nationhood and the National Question in the New Europe, Cambridge

University Press, Cambridge.

Byrne, B.

2004 "Qualitative Interviewing”, in Clive Seale (Ed), Researching Society and Culture, Sage

Publications, London.

Crampton, $\mathrm{R}$.

1997 A Consice History of Bulgaria, Cambridge University Press, Cambridge.

Dale, A.

2006 “Quality in Social Research”, International Journal of Social Research Methodology, 9(2): 79-82.

Dayığlu, A.

2005 Toplama Kampından Meclis'e: Bulgaristan'da Türk ve Müslüman Azınlığı, İletişim Yayınları, İstanbul.

Dirjavna Agentsiya "Arhivi"

2009 “Vizroditelniyat protses” Bllgarskata Dırjava i Bılgarskite Turtsi: Sredata na 30-te - Naçaloto na 90-te Godini na XX vek. Tom I - Tom 2, Dirjavna Agentsiya “Arhivi”, Sofia.

Diez, T. et al.

2008 The European Union and Border Conflicts: The Power of Integration and Association Cambridge University Press, Cambridge.

Dimitrov, V.

2000 "In Search of a Homogeneous Nation: The Assimilation of Bulgaria's Turkish Minority, 1984-

1985", Journal of Ethnopolitics and Minority Issues in Europe, 1(4): 1-22.

Dimitrova, R. et. al.

2013 "Collective identity and wellbeing of Roma minority adolescents in Bulgaria", International Journal of Psychology, 48: 502-513.

2014a "th in Bulgaria and the Netherlands: A Comparative Study of Their Acculturation Orientations and Outcomes”, International Journal of Intercultural Relations, 40: 76-86. 
2014b "From a Collection of Identities to Collective Identity: Evidence From Mainstream and Minority Adolescents in Bulgaria", Cross-Cultural Research, 48: 339-367.

2014c "Collective Identity and Well-Being of Bulgarian Roma Adolescents and Their Mothers", Journal of Youth and Adolescence, 43: 375-386.

2015 "Heritage Identity and Maintenance Enhance Well-Being of Turkish-Bulgarian and TurkishGerman Adolescents", Social Psychology, 46(2): 93-103.

Dimitrova, R. and A. Aydinli-Karakulak

2016 "Acculturation orientations mediate the link between religious identity and adjustment of TurkishBulgarian and Turkish-German adolescents", SpringerPlus, 5(1): 1-11.

Dzhambazova, B.

2017 “As Support for E.U. Flags Elsewhere, Bulgaria Sees Its Benefits", New York Times, January 16.

Eckstein, $\mathrm{H}$.

1975 "Case Study and Theory in Political Science", in F. Greenstein and N. Polsby (Eds), Handbook of Political Science, Addison-Wesley, Reading; 79-138.

Eminov, A.

1999 "The Turks in Bulgaria: Post-1989 Developments", Nationalities Papers, 27(1): 31-55.

European Commission

2004 Regular Report on Bulgaria's Progress towards Accession, 6.10.2004, SEC (2004) 1199,

European Commission, Brussels.

Fiddian-Qasmiyeh, E. et. al.,

2014 The Oxford Handbook of Refugee \& Forced Migrated Studies, Oxford University Press, NewYork.

George, A.L., and A. Bennett

2005 Case Studies and Theory Development in the Social Sciences, MIT Press, Cambridge.

Ghodsee, K.R.

2009 Muslim Lives in Eastern Europe: Gender, Ethnicity, and the Transformation of Islam in Postsocialist Bulgaria, Princeton University Press, Princeton.

Government of Bulgaria

2012 Deklaratsiya: Osŭzhdashta Opita za Nasilstvena Asimilatsiya na Bŭlgarskite Myusyulmani.

Available online at: http://www.parliament.bg/bg/declaration/ID/13813 (accessed on 2 June 2016).

Hall, P.A.

2013 "Tracing the Progress of Process Tracing", European Political Science, 12(1): 20-30.

Halperin, S. and O. Heath

2012 Political Research: Methods and Practical Skills, Oxford University Press, Oxford.

Helsinki Watch

1986 Destroying Ethnic Identity: The Turks of Bulgaria. Helsinki Watch, New York.

1987 Destroying Ethnic Identity: The Turks of Bulgaria, An Update. Helsinki Watch, New York.

Kalinova, E. 
2014 "Remembering the "Revival process" in Post-1989 Bulgaria", in M. Todorova, A. Dimou and S. Troebst (Eds), Remembering Communism, Private and Public Recollection of Lived Experience in Southeast Europe, Central European University Press, Budapest; 567-594.

Kanev, K.

2007 "Muslim Minorities and the Democratisation Process in Bulgaria", in M. Hacısalihoğlu and F. Aksu (Eds), Proceedings of the International Conference on Minority Issues in the Balkans and the EU, OBIV, İstanbul: 79-88.

King, G., R.O. Keohane, and S. Verba

1994 Designing Social Inquiry: Scientific Inference in Qualitative Research, Princeton University Press, Princeton.

Kolarova, R.

1993 "Tacit Agreements in the Bulgarian Transition to Democracy: Minority Rights and Constitutionalism", The University of Chicago Law School Roundtable, 1(1): 23-51. Available online at: http://chicagounbound.uchicago.edu/roundtable/vol1/iss1/12 (accessed on 7 June 2016).

Konukman, R.E.

1990 Tarihi Belgeler Işı̆̆ında Büyük Göç ve Anavatan: Nedenleri, Boyutlarl, Sonuçlarl, Türk Basın Birliği, Ankara.

Korostelina, K.

2009 "Identity Conflicts: Models of Dynamics and Early Warning", in D.J.D. Sandole et al. (Eds),

Handbook of Conflict Analysis and Resolution, Routledge, London; 110-116.

Kutlay, M.

2012 "Historical Decision of the Bulgarian Parliament", Journal of Turkish Weekly. Available online at: http://www.turkishweekly.net/2012/01/14/op-ed/historical-decision-of-the-bulgarian-parliament/ (accessed on 22 May 2016).

Özgür, N.

1999 Etnik Sorunların Çözümünde Hak ve Özgürlükler Hareketi, Der Yayınları, Istanbul.

Lewis, S.

1994 "Islam in Bulgaria”, Aramco World, 45(3): 20-29.

Lilleker, D.G.

2003 "Interviewing the Political Elite: Navigating a Potential Minefield", Politics, 23(3): 207-214.

Mann, M.

2005 The Dark Side of Democracy: Explaining Ethnic Cleansing, Cambridge University Press, Cambridge.

Mansfield E. and J. Snyder

2007 Electing to Fight: Why Emerging Democracies Go to War?, MIT Press, Cambridge.

McDowell, C.

2014 "Development Created Population Displacement" in E. Fiddian-Qasmiyeh (et. al.), The Oxford Handbook of Refugee \& Forced Migrated Studies, Oxford University Press, NewYork; 330-341.

Mevsim, H.

2013 "Arşivlerin Tozlu Yapraklarından: Bulgar Ulusunun Birliği; Kıymetli Vatanımızın Her Yurttaşının Derdi ve Yazgısıdır, 29 Mayıs 1989”, in H. Mevsim and M. Kutlay (Eds), Tarihe Not Düşmek: 1989 Göçü Kitap Serisi, USAK Yayınları, Ankara; 20-27. 
Mevsim, H. and M. Kutlay (Eds)

2013 Tarihe Not Düşmek: 1989 Göçü Kitap Serisi, 6 Volumes, USAK Yayınları, Ankara.

Nitzova, P.

1997 "Bulgaria: Minorities, Democratization, and National Sentiments", Nationalities Papers, 25(4): 729-739.

Noutcheva, G. and D. Bechev

2008 "The Successful Laggards: Bulgaria and Romania's Accession to the EU", East European Politics and Societies, 22(1): 114-144.

Papadimitriou, D. and E. Gateva

2009 "Between Enlargement-Led Europeanization and Balkan Exceptionalism: An Appraisal of Bulgaria's and Romania's Entry into the European Union", Perspectives on European Politics and Society, 10(2): 152-166.

Parla, A.

2006 "Longing, Belonging and Locations of Homeland among Turkish Immigrants from Bulgaria", Southeast European and Black Sea Studies, 6(4): 543-557.

2007 "Irregular Workers or Ethnic Kin? Post-1990s Labour Migration from Bulgaria to Turkey", International Migration, 45(3): 157-178.

2009 "Remembering Across the Border: Postsocialist Nostalgia among Turkish Immigrants from Bulgaria", American Ethnologist, 36(4): 750-767.

Phinnemore, D.

2009 "From Negotiations to Accession: Lessons from the 2007 Enlargement," Perspectives on European Politics and Society, 10(2): 240-252.

Poulton, $\mathrm{H}$.

1993 The Balkans: Minorities and States in Conflict, Minority Rights Groups, London.

Rechel, B.

2007 "State Control of Minorities in Bulgaria", Journal of Communist Studies and Transition Politics, 23(3): 352-370.

2008 "What Has Limited the EU's Impact on Minority Rights in Accession Countries", East European Politics and Societies, 22(1): 171-191.

Republic of Bulgaria, Ministry of Interior

1989 "The Numbers of People who took their Bulgarian Names back", No:397, 27/5/1989.

Rumelili, B.

2007 "Transforming Conflicts on EU Borders: the Case of Greek-Turkish Relations," Journal of Common Market Studies, 45(1): 105-126.

Silverman, D.

2011 Interpreting Qualitative Data: A Guide to the Principles of Qualitative Research, Sage Publications, London.

Stefanovic, D., and N. Loizides 
2011 "The Way Home: Peceful Return Victims of Ethnic Cleansing”, Human Rights Quarterly 33(2): 408-430.

Stefanovic, D., N. Loizides and S. Parsons

2014 "Home is Where the Heart is? Forced Migration and Voluntary Return in Turkey's Kurdish Regions", Journal of Refugee Studies, 28(2): 276-296.

Vachudova, M.A.

2005 Europe Undivided: Democracy, Leverage, Integration after Communism, Oxford University Press, Oxford.

Vromen, A.

2010 "Debating Methods: Rediscovering Qualitative Approaches" in David Marsh and Gerry Stoker (Eds), Theory and Methods in Political Science, Palgrave Macmillan, Basingstoke.

Warhola, J.W. and O. Boteva

2003 "The Turkish Minority in Contemporary Bulgaria", Nationalities Papers, 31(3): 255-279.

Yarris, K., and H. Castaneda

2015 "Discourses of Displacement and Deservingness: Interrogating Distinctions between 'Economic' and 'Forced' Migration”, International Migration, 53(3): 64-69.

Zhelev, Z.

2008 In at the Deep End, Trud Publishing House, Sofia. 